\title{
Teens dealing with MRKH syndrome to achieve self-actualization: is it unequal gender decision?
}

\author{
Retty Ratnawati ${ }^{1}$, Gardha Rias Arsy ${ }^{2}$ \\ \{retty.fk@ub.ac.id ${ }^{1}$, gardarias051@gmail.com ${ }^{2}$ \}
}

Master Degree Program of Women Studies \& Physiology Department, Faculty of Medicine, Universitas Brawijaya ${ }^{1}$, Master Degree Program for Nursing, Faculty of Medicine, Universitas Brawijaya ${ }^{2}$

\begin{abstract}
Mayer Rokitansky Kuster Hauser Syndrome (MRKH) is the condition when the uterus and/or the vagina are underdeveloped in female. The chief complaint is mostly not getting menstruation. The surgical treatment is thought to be the best cured. However, the psycho-socio aspect when the MRKH syndrome was diagnosed, and then the struggle of the patients and their families, just begins. Therefore, the research question in this preliminary study was about their strategy to deal with MRKH syndrome. Our participants were three teenagers aged 16-19 year old. The in-depth interview was used to collect the data. The results showed that their parents were confused and stressed out. The patients were diagnosed as having no uterus or vagina, even though they had the ovarium. To have the treatment by surgical approach would not be useful for them, so the alternative medicine became another solution to seek treatment (such as massage, to see the 'kyai' or others). It is concluded that psychosocial aspect became a more dominant problem to deal with in patients with MRKH syndrome. It is suggested that they seek professional and community assistance to overcome this almost neglected problem.
\end{abstract}

Keywords: Mayer Rokitansky Kuster Hauser Syndrome, teenager, self-actualization, psycho-socio aspect.

\section{Introduction}

Mayer Rokitansky Kuster Hauser Syndrome, known as MRKH, is a congenital condition in female characterized by underdeveloped fallopian tubes, vagina, and uterus [8], though ovarium is normally present. The prevalence of MRKH syndrome presents in female is 1:5000 [10]. The condition of MRKH syndrome developed when a woman enters puberty and has not yet experienced menstruation (amenorrhea primer) [12]. As ovarium still present, MRKH women physically show no hormonal disorders. Biomedically, however, obstruction happens in Mullerian duct that later develops into uterus, fallopian tubes, cervix, and vagina.

Problems in the female reproductive organs can affect the quality of life in women because the female reproductive organs are considered as the identity of a woman's perfection [11]. Research and medication surrounding MRKH are mostly focused on medical-physical aspects, such as constructing neovagina, widening vagina, and uterus transplantation.

The psychological state of MRKH women is usually disrupted, such as distress and anxiety [6]. Where as Bean research get various reactions to the diagnosis of MRKH including depression, shock, questioning self-identity, selfrole both socially and sexually, fear of partner rejection, and different feelings [2]. The inability to carry a child has been suggested to be one of the most distressing effects of $\mathrm{MRKH}$, and therefore may have a strong impact on women's wellbeing [9]. It will eventually making a decrease in quality of life and disturbance of self-concept in women with MRKH [1]. A suicide of a 19 years old female has been reported in New Delhi, India [5]. In reality, having a biological child for MRKH women is possible because of the ovary that is generally normal and, thus, the 
availability of surrogate pregnancy [10]. In Indonesia, however, surrogate pregnancy is still uncommon. Married MRKH women face psychological crises and may end in divorce, sexual-psychological-physical-economic violence, loss of confidence, distress [1]. Therefore, this study aimed to determine the meaning of experience in women with MRKH.

\section{Method}

This study used a qualitative research design with an interpretative phenomenology approach. Participants involved in this study were 7 (seven) people with the following criteria; women with MRKH, living in Kudus Regency, Indonesian Citizens, and willing to become participants. One participant was a high school student and two participants were college students. Data collection was done by in-depth interviews. The interviews were recorded using a voice recorder application in Vivo smartphone on the approval of the participants. The duration of the interview for each participant was around 30-60 minutes.

Data analysis uses the principle of Interpretative Phenomenological Analysis (IPA) data analysis to determine themes and meanings.

\section{Results}

The analysis from participants' data resulted in 4 main themes. The themes and sub themes are explained as follow.

\section{Theme 1: The feeling of physical disability/defect}

The word defect means a deficiency that lessens a quality. The feeling of physical disability is built from the following two subthemes.

\section{1.a. Shock from knowing the state of the syndrome}

When first knowing the doctor's diagnosis on the state of their reproductive health, the participants gave various responses. Some were devastated (terpukul). According to the Great Dictionary of Indonesian Languange (KBBI), terpukul or devastated implies the feeling of shock and helplessness. The following are some quotes from the participants:

"of course I was shocked, I limped and sat on the chair crying. My Mom also cried after telling me the news. Mom was devastated, crying while telling me this, "what about your future? Dear God." After that I cried even harder.." (p1)

"Don't ask me, it felt chaotic. I was feeling messy. The moment I knew that I have this disorder, I was limped, gawking like a fool.. so many questions in my head.. Why? Why? Huff, sad, crying.. Why me? It was like that." (p2)

"I felt sad, I could only cry, slumped, feeling uncomfortable at home, but it can be helped. Who should I blame..?" ( $p 7)$

The statement above showed how participants gave different responses on how they face the bad news. Some participants were shocked and some were sad, embarrassed, until slumped knowing the state of their female reproductive abnormalities.

\section{1.b. Feeling physically imperfect and psychologically distressed}

The subtheme of feeling physical imperfect invisibly gave meaning that participants felt lacking, imperfect, and defective albeit looking perfect in appearance. The participants seemed as fine as other females but 
they differ only in terms of reproductive system. This made them thinking that they are defective. The following quotes were

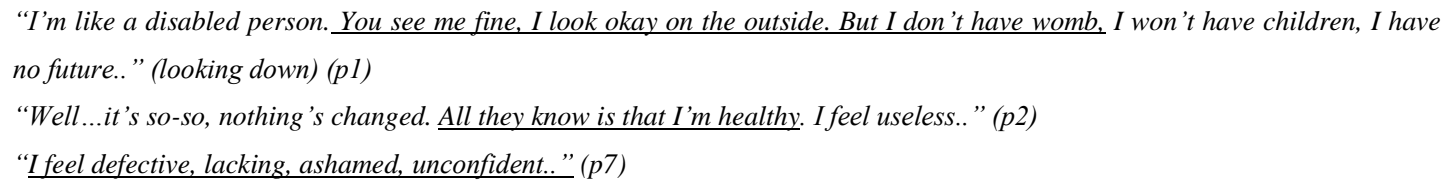

The statement above shows how participants feel themselves as defective even though they look 'good' and healthy.

\section{Theme 2: Consider "curse" as the cause of the syndrome}

The theme of considering "curse" as the cause of the syndrome was expressed by participants with various psychological complaints. The family believed that the conditions experienced by the participant were due to some mistakes of the parents when they were pregnant. The word "curse" (tulah) itself has the meaning of a result of violating customary rules (KBBI, 2014). This theme was built on the following subthemes.

\section{2.a. Curse from parents' mistake}

The sub-theme of curse from parents' mistake emerged after a relative of the father told them about ancestors' beliefs of closing a hole when the participant's mother was pregnant would lead to the suffer on reproductive health.

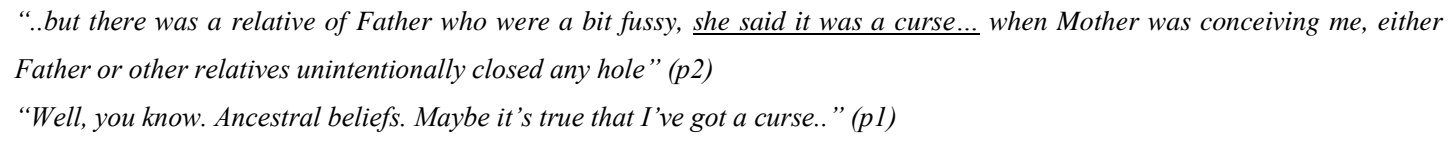

The aforementioned statement showed that the participants believed that they were cursed when their parents violated some ancestral beliefs.

\section{2.b. Curse bringer}

A curse is a terrible incident that befalls upon someone (KBBI, 2014), as expressed by the participants in the following.

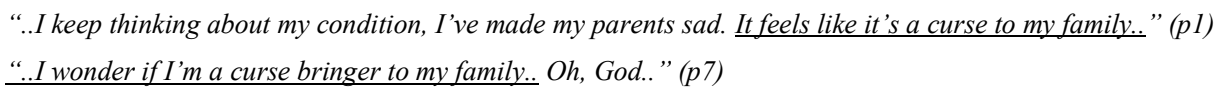

The statements above showed that participants took themselves as the curse bringer to the family.

\section{Theme 3: Fear of inability to fulfill the destiny as a woman}

This theme depicts the meaning of imperfectness felt by the participants due to their syndrome. This built upon the following three subthemes.

\section{3.a. Fear of experiencing failure in marriage}

In this subtheme, participants were afraid of failing in future marriage due to imperfect reproductive organ. They felt they would not succeed in matrimony. The unwed participants experienced anxiety and fear about their future partner, that they will be dumped, and that they will never get a partner.

“Sometimes I just don't feel complete, I'm losing confidence, especially when some relatives commented on how I will build my

family, no man would want me because I can't give offspring.. " ( 2 2)

“..I could be divorced midway later..” (wiping tears with jilbab) (p1) 
The statement above showed that participants experienced anxiety, fear of failure at their marriage or household.

\section{3.b. Desperate about life companion}

The subtheme of desperate about life companion gave meaning that participants yearn for marriage but afraid that no man is willing. The participants expressed as follow.

"I'm pretty much sure, but it's almost impossible. There are two possibilities, no one wants to marry me if they know my shortcoming from the beginning..” (p1)

“..tired, I'm feeling desperate..” (looks away) (p2)

These participants' statements showed the meaning that they felt it is impossible to get a husband and marriage companion. The participants also felt tired and desperate.

\section{3.c. Keeping her condition as MRKH woman a secret}

Thinking that having this syndrome would certainly unable them to have children, the participants never told anyone other than their parents. Participants quote:

“.. There are two possibilities; no one wants to marry me if they know my shortcoming from the beginning. So I won't tell anyone.." $(p 7)$

\section{Theme 4: Determined to actualize themselves despite experiencing "special circumstances"}

This theme conveyed self-actualization despite experiencing special circumstances, portrayed the meaning in which participants could perform feminine roles, albeit one role was inexecutable. This theme is built from 3 sub themes below:

\section{4.a. Dating normally}

The age of adolescents, in which they started to sexually active, is still being performed by participants.

The following is an example of an interview excerpt

“...well, I'm enjoying it, the date. I just broke up with my last ex. I'm with my new boyfriend now. He is good, willing to take me to hospital.. to complete this MRKH diagnosis. He knows I have MRKH. We're on the good term until now. About marriage.. we'll think about it later." ( $p 7)$

\section{4.b. Wishing for better future}

This subtheme described the participants' wishes about their future. The following are examples of quotes from participants:

\footnotetext{
"..I can only focus on my study, and helping my parents.. so that I can make them proud though I can't give them grandchildren.." (p1)

"That's why I'm determined to go to college.. I'll just study, spending my life for studying, and praying. If needed, I'll take my master degree abroad.." ( 2 2)
}

The participant's statement above gave meaning that they wanted to try to make their parents proud even though they were lacking; that they could never give biological offspring.

\section{4.c. Want to be an independent woman}

This subtheme of running the role of a woman independently illustrated how participants were able to perform other roles as a woman despite the shortcoming in reproductive organ system.

"That's why I'm determined to go to college.. I'll just study, spending my life for studying, and praying. If needed, I'll take my master and doctoral degree abroad.." ( $p 2$ ) 
The statement above gave meaning that the participant has devoted her life to worship, to continue studying for her future, and to have career. Participants tried to empower themselves, carried out other roles and refused to give in to their shortcomings.

\section{Themes Interaction}

The interrelationship between themes in this study focused on the participants' effort to actualize themselves, illustrated as a continuous cycle. The results of the theme in this study explained the psychological meaning experienced by teenage MRKH participants.

They initially experienced downturn; a conflict emerged in her self-acceptance after knowing the shortcomings in their bodies.

The life journeys of the MRKH participants were full of struggles and life difficulties because of the illness they experience, but they did not stand by and give in. They believed and were sure they could still work and tried to grow in hardship. This was reinforced by the reality faced by the participants. They wanted to live independently, to continue working, and were passionate about pursuing higher education and comfortable being young women who were sexually active, still dating the opposite sex well. They always want to prove that they were also capable like other women.

\section{Discussion}

The psychological states between married and unmarried women with MRKH were different [1]. Married participants experienced violence, both psychologically and physically, by their partners and feel trapped in a marriage. Several things affected the psychological state of married MRKH participants, including depression. Nevertheless, they still preserved their marriage at all risk, as it has a high social status in Indonesia. This condition was supported by the country which define divorce as the following

“...One party has a disability or illness which causes an inability to carry out its obligations as a husband and wife...” (Explanation of Article 39 Paragraph (2) of Marriage Law and Article 19 in Government Regulation no.9 of 1975 on the implementation of Law No. 1 of 1974 on Marriage)

These teenage participants prefer to try to actualize themselves even despite the disapproval of their surroundings. Such concerns included parents who were worried about the future of their daughter, the fear that the daughter cannot have children, on top of public perception in which unmarried woman is a misfit. The pressure from the surroundings has made the participants withdrawn themselves and need time to settle down. Withdrawing and feeling threatened by the presence of other people nearby is a feature of a person experiencing social isolation disorder [4].

The participants' parents had concerns regarding their daughter's future, especially the relationship with her boyfriend. Having a committed relationship was one of Indonesian expressions of being sexually active, which was quite different compared to foreign countries. Here, sexually active in puberty did not lead to free sex but rather the readiness to face marriage life. 
Participants should have been informed that there was an opportunity for them to have biological children, i.e. through surrogate pregnancy, as one of the MRKH therapies [12]. It was, however, difficult—even impossible - to be implemented in Indonesia. This possibility should be taken into consideration.

The concept of marriage in Indonesia is different from other countries in which producing offspring become an option instead of an obligation. Marriage is a sacred commitment to God and hurting the partner is not allowed. While in the explanation given by Dunvall [3], marriage is a relationship that involves sex between men and women in legitimate household. In the case of MRKH, vaginoplasty surgery may be performed when biological relationship became the purpose.

The therapies sought for MRKH women abroad are numerous and varied, one of which is vaginoplasty surgery. Vaginoplasty can be performed on patients who have imperfectly formed vagina. In this surgery, a dilator is used as vaginal formation aid and is supported by trained and professional health personnel with complete equipments [7]. This surgery is still uncommon in Indonesia. The focus of laboratory examinations for MRKH diagnoses will seem unfavorable, even financially burdensome, if not accompanied by counseling therapy that is urgently needed by present MRKH women. The participants were only recommended to take medical examinations, such as genetic tests, chromosome tests, and laparoscopic actions. In reality, the provision of medical action is more dominating than psychological counseling.

Psychological counseling therapy should be recommended for accompaniment and mental strengthening on young women with MRKH, though this has yet to be implemented regularly. As found in the theme of various psychological problems in which participants must solve themselves, they were trying hard to make peace with themselves so that they can overcome psychological problems arising from the conditions experienced since the supporting system for psychological therapy has not been properly provided. The participants were aware of the existing promotive therapy, such as online service Hello Sehat, though they felt that it was insufficient. This notion was in contrast with developed countries, such as America. The Boston Children Hospital, which has recorded the experiences of MRKH women in their book The Art of Healing (2018), has become a positive reference for women with MRKH.

In conclusion, the most important meaning from the experience of teenagers with MRKH was to be able to actualize themselves in the future even though they may choose not to marry. In addition, these participants were also struggling to overcome psychological problems that came from within themselves and their surroundings. It is suggested that the government should start to consider and formulate a law on surrogate pregnancy as well as to encourage supporting system, such as counseling or supervised patient association, for women with MRKH.

\section{Reference}

[1] Arsy, GR, Ratnawati, R \& Rachmawati SD (2019). Low self-esteem of women suffering MayerRokitansky-Kusher-Hauser syndrome. Indian Journal of Public Health Research \& Development (in Press)

[2] Bean, E., Mazur, T., \& Robinson A. D. (2008). Mayer Rokitansky Küster Hauser Syndrome: Sexuality, Psychological Effects, and Quality of Life. Journal of Pediatric and Adolescent Gynecology. 22, 339-346. 
[3] Duvall, E. M., \& Miller, B. C. (2012). Marriage and Family Development (6 ${ }^{\text {th }}$ Ed). New York: Harper \& Row

[4] Fortinash \& Worret. (2011). Psychiatric Mental Health Nursing. (5 ${ }^{\text {th }}$ ed.). St. Louis: Mosby.

[5] Gupta, M., \& Kharb, V. (2012). MRKH Syndrome: Psychological Disturbances and Suicide. Journal of Indian Academic Forensic Medicine, 34(1), 86-88.

[6] Heller-Boersma, J., Schmidt UH, Edmonds DK. (2009). Psychological Distress in women with Uterovaginal agenesis (Mayer Rokitansky Kuster Hauser Syndrome, MRKH). Psychosomatics, 50: 277-281)

[7] Irawan, Andre. (2016). Pandangan Hukum Islam tentang Operasi Keperawanan sebagai Alasan Untuk Memperlancar Pernikahan. Jakarta, Fakultas Syari'ah dan HukumUniversitas Islam Negeri Syarif Hidayatullah.

[8] Ismail PI., \& Bikoo, M., (2007). Normalization of the vagina by dilator treatment alone in Complete Androgen Insensitivity Syndrome and Mayer Rokitansky Kuster Hauser Syndrome. Human Reproduction, 22(7), 2020-2024.

[9] Kimberley, N., Hutson, J.M., Soutwell, B. R. \& Grover , S. R. (2011). Well-being and sexual function outcomes in women with vaginal agenesis. Fertility and Sterility. 95(1). p. 238-41.

[10] Londra L., Chuong FS, Kolp L. 2015. Mayer Rokitansky Kuster Hauser syndrome: A review. Int. J Womens Health 7: 865-870

[11] Mungadi, I.A., \& Ahmed, Y. (2010). Mayer Rokitansky Kuster Hauser Syndrome: Surgical management of two cases. Journal of Surgical Technique and Case Report. 2(1). p. 39-43.

[12]Patnaik, S., \& Brazile, B. (2015). Mayer Rokitansky Küster Hauser (MRKH) Syndrome: A historical perspective. Gene, 555, 33-40. 